\title{
Flood prevention method
}

\section{Introduction}

Annually in the world, the number and destructiveness of floods is increasing. The causes of floods are increased precipitation, regulation of releases and destruction of reservoirs, climate change. No wonder they say that you cannot enter into the same river twice. The rivers continuously raise the level of bottom sediments. The movement of water blurs the coast in its endless current, but most of the bottom melts during floods, when water washes into the river everything that lies on the coastal territories - loose soil, sand, clay, various objects and masses, garbage. These accumulations most of all gather below the settlements, forming underwater dams.

The outflow of water from the coast occurs, mainly, in such places. They are invisible from the land, but the throughput of rivers decreases within and below towns and cities along the current. Therefore, floods and heavy precipitation are flooding with the destruction of buildings, roads and everything else.

If you remove these underwater banks, then the water outflow from the shores, at least, will move downstream, beyond the settlements.

For this, first of all, it is necessary to measure the depths of the rivers where the waters leave the coast, reveal the dimensions of the rifts and, instead of stacking sandbags and building dams, it is necessary to deepen these sections of the rivers immediately after, and during the floods. It is possible to plan in advance the places of floods and to take them away from habitation and constructions. This is possible on the rivers of lowland slopes. On rivers with a large incline floods can be completely excluded.

Existing technologies of dredging are based on excavation, bulldozer cleaning and dredging with expensive serial equipment with pollution of coastal areas and, incredibly, with great financial and material costs. Modern dredgers with a capacity of $100-800$ $\mathrm{kW}$, as well as their rent are not available to every coastal farm. Giant monsters on the river consume rivers of fuel and pollute the environment, for example ${ }^{1}$ (Figure 1).

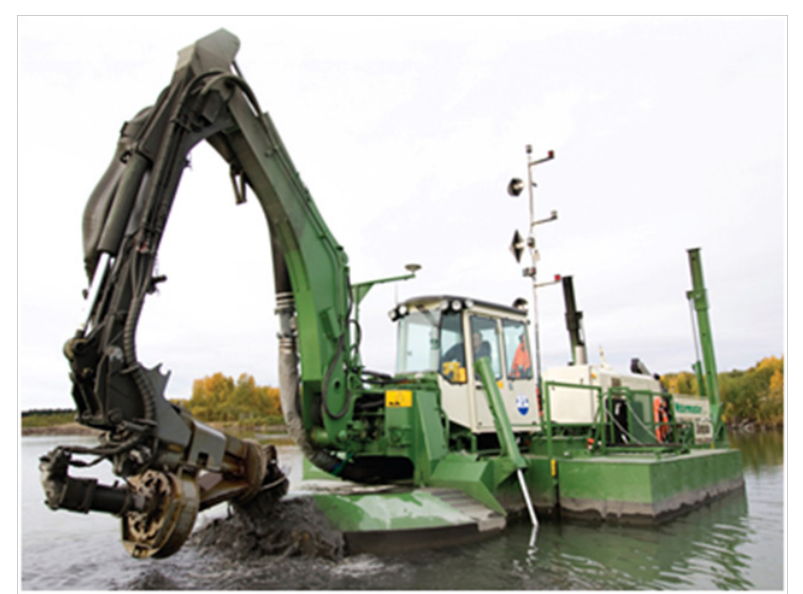

Figure I Flood Situation on the territory of the North-Kazakhstan region.
Volume 6 Issue 3 - 2017

\author{
Oleg Halidullin,' Salnikov VG, ${ }^{2}$ Duskaev KK ${ }^{3}$ \\ 'Kazakh National University, Russia \\ ${ }^{2}$ Doctor of geographical sciences, Russia \\ ${ }^{3}$ Department of technical sciences, Russia
}

Correspondence: Oleg Halidullin, Kazakh National University, Alb-Farabi, Russia, Email 7II52I5@mail.ru

Received: August 28, 2017 | Published: September 15, 2017

The great Austrian hydraulic engineer Victor Schauberger once wrote that rivers can self-clean. Indeed, this is possible if the bottom of the rivers is formed in such a way as to give the flow of water a spiral motion.

In fact, the natural movement of water in the river tends to this form of flow - meandering. The process of formation of the river bed is constantly, gradually and continuously changing. In this case, rather large bends of the river are obtained, constantly increasing the total width of the floodplain. The consequence of the expansion is the collapse of the coast, the agricultural areas are being cut, houses and buildings are being destroyed. The bottom alternates with rolling and rolling, which slowly move downstream. Exit to the sea or lake also raises the bottom, which leads to the expansion of the delta of rivers, spreading into new channels, loss of water to impregnate new areas, to evaporation. Lakes become shallow and degraded, and, ultimately, leads to the fact that these lakes dry up, for example, the Aral, Balkhash is next in line.

Developments have been developed that use the forces of the river to form the river bed and river bed, within specified limits, with given depths for passing ships, with straightening bends, and controlling water flow. There are opportunities to influence meandering processes by the simplest means. Manufacture and operation of such facilities are available to small coastal farms that suffer from floods, collapse of shores, shallowing of fairways.

Work on the deepening of the rolls should be started during and immediately after the floods - with strong water movements to prevent floods next year. In the low period, in the summer, the effectiveness of such work is reduced because the water flows in the rivers are decreasing, and some rivers are completely dry.

The proposed method of influencing bottom sediments by the current itself is based on the constraint and control of part of the stream to affect bottom sediments. Devices change and concentrate river flows, without requiring any energy at all. The technological process is carried out by directing a part of the flow to pre-selected 
places in the channel, creating zones of erosion of bottom sediments. Depending on the parameters of the river, the devices are controlled from the shore by cables or supplemented with mobile transport means. Structurally, the devices depend on the thickness of the streams, the width and depth of the river.

New means can affect the bottom and the shore without the use of energy. Passive devices made of shields, reinforced and controlled by cables or mobile floats, can straighten river beds in pre-designed forms.

The patent office is considering an application for combining this principle with the implementation of all known dredging and more - an entirely new direction is being created leading to a new technology for underwater works. $\mathrm{T}$ firmly stand at the bottom and control the flow of water. A change in buoyancy and sail make it freely move over the surface of the water and under water. It is possible to interface it known devices for all kinds of hydraulic works: Search and Recovery subjects, the use of dredges, sawing surface and underwater branches and trunks of trees, flushing lifting sub-wood and drowned objects. Management and concentration of flows create absolutely new opportunities not only for the formation of the riverbed. There is a new technology for underwater works, for example, sorting bottom deposits, with the removal of the finished fractions, minerals, for example, gold. Flow control almost does not require energy. The recognized patent purity of the technical solution, the logical sequence of essential features that are necessary, and all taken together, are sufficient to make this object workable. Tests of individual elements of micro models of the proposed device on small rivers and trays were conducted, which showed the result. Design work and tests are required to test and demonstrate the effectiveness of the new method in full-flow river conditions. The first experience on a natural object can start a widespread deepening of the rifts on all rivers, where floods occur and warn them in the nearest flood. The designs of such devices are developed for each type of water body. From small rivulets Kazakhstan - Kaskelenki, Almatynki to great rivers, such as the Irtysh, the Urals, the Mississippi and the Amazon. The proposed devices can save water from spreading and evaporating, narrow the delta, restore shipping. To do this, it is necessary to restore the main - the historical channel. To save water for the summer period, it is customary to build reservoirs based on dams and dams. Practice shows that abnormal precipitation leads to the breakthrough of such dams and floods. The reasons leading to this are also the longterm sedimentation of the reservoir itself by deposits from rivers. Periodically, it is necessary to clean the bowl of the reservoir from sediments. The proposed principle of cleaning the bottom of rivers can be applied here. Strategically building reservoirs, by damaging rivers with dams, is a crime against nature and a high risk of flooding. To save the water in the middle, it is enough to deepen the stretches - the existing depths. Deepening of existing reservoirs to the required volumes of accumulation can allow to drain previously flooded areas and eliminate dams - the main sources of man-made disasters. The design of the machine with the screw can be used in inverse mode to create a watercourse in slow flowing rivers and, in standing reservoirs. A device with a turned screw in the opposite direction, which stands firmly at the bottom, creates the necessary water flow, provides visibility in the development zone. And power-enhanced screws can stir up and move bottom sediments. In essence, an absolutely new vehicle is proposed, moving along the bottom of the reservoir and performing hydrotechnical work. And if you supplement it with a caterpillar drive, it becomes an amphibian - a car going out on land. There are a few additions that create new opportunities, not only in flood prevention, but also in the development of new technologies for work under water.

\section{Applications}

\section{i. Description of the patent}

ii. A summary of the catastrophic floods in Kazakhstan in the spring of 2017.

Eurasian (21) (13) Patent Office (12) specification of a Eurasian APPLICATION (43) Date of publication of application: (51) Int. Cl.KZ2009 / 017 (KZ) 2009.09.07HALIDULLIN Oleg Hanyshevich (KZ).

Method for Cleaning and Strengthen riverbeds and a device Deposits from The Bottom for Osuschestvleniyaa:

Izobretenie relates to a hydraulic construction and can be used for the purification of river channels, channels of nano-cos. In the purification process and deepening riverbeds of sediment blurry water flow, which is created with a mobile device vodostesnitelny mstruenapravlyay uschimi elements scouring water flow is affected by setting vodostesnitel nogo device struena pravlyayuschimi elements on the floating means advantageously at its bottom part. In this case, a zone of erosion is formed under the bottom of the floating device. Floating means are moved along the channel at a rate that ensures erosion of bottom sediments. Before the clearing and deepening of the channel, the relief of the bottom sediments is determined beforehand. Undiluted part of the bottom sediments are destroyed by mechanical action of additional devices placed on the water-resistant device. The water-diffusive device with stream-guiding elements contains longitudinal ribs fixed mainly on the bottom part of the floating means, the jet-guiding elements are made in the form of shields mounted on the end parts of the longitudinal ribs hingably with the possibility of adjusting the gap between them. They form a cavity above the surface of the river bottom. Cutters in the form of plough shanks are made with the possibility of changing the direction of their edges. Cutters in the form of screws or rotors are equipped with drives. Drives of screws or rotors are made in the form of blades driven into the rotation by a stream of water (Figure 2).

A method for preventing flood control and water flow in a river flood period and a device for osuschestvleniyaNomer RK patent: 26962.

Opublikovano: 15.05.2013 Author: Halidullin Oleg HanyshevichFormula/ReferatIzobretenie relates to a hydraulic construction and can bytispolzovaniya to prevent flood control and water flow of the river floods period.

The technical result with the use of the proposed invention is to provide the possibility of erosion of the rolls with the passage capacity STI river vessels for movement along the predetermined fairway, excluding formation on reke. Izmeryayut flood water levels in adjacent stretches with identifying the location of sills, scouring water stream is directed onto rolls, and control water flows in the river flood period ensured by the gasket fairway movement vodostesnitelyyugo Devices along the riverbed along the trajectory of the future fairway. The waterproof device is made in the form of rigidly connected among themselves parallel oriented vertical floats their shields and gaskets for the channel in the apparatus additionally introduced adjustable flexible compounds which alter location vodostesnitelnogo devices in the longitudinal and movement psevdopoperechnom aqueous stream napravleniyah river. 


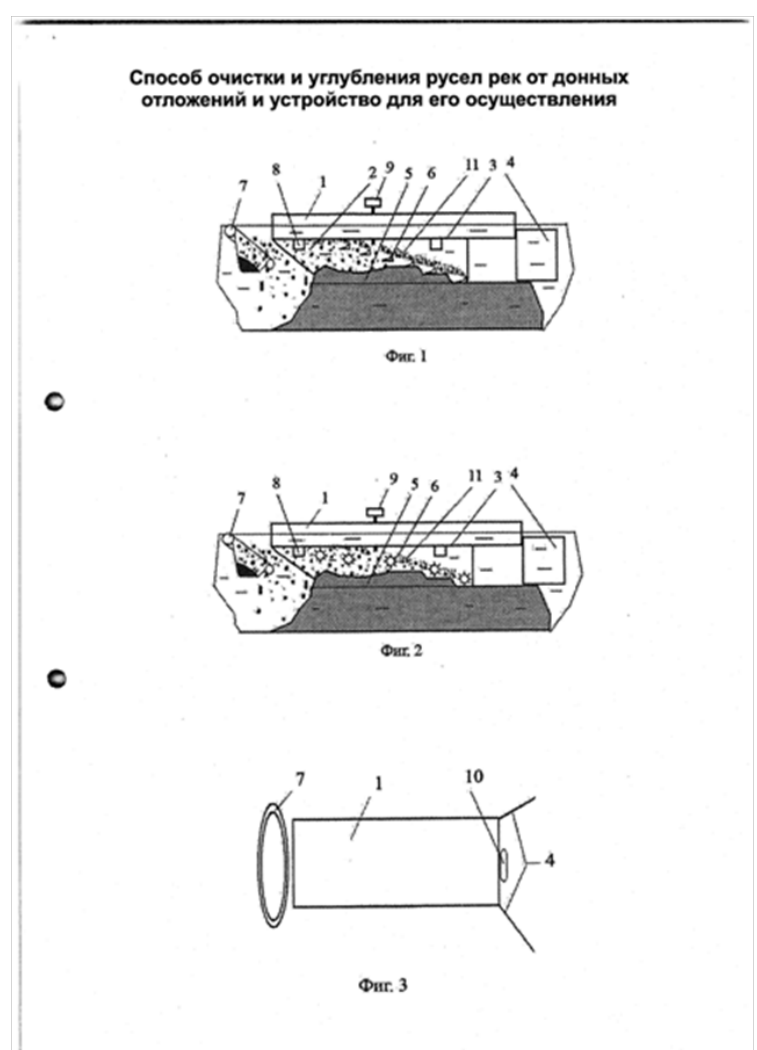

Figure 2 Drives of screws or rotors are made in the form of blades driven into the rotation by a stream of water.

The purification process of sediment and recesses riverbeds and device for osuschestvleniya Nomer innovative patent RK: 296230 publikovano: 16.03.2015Avtory: Duskaev Kasym Koyanbaevich, Salnikov Vitaliy Grigorevich, Halidullin Oleg HanyshevichFormula / ReferatIzobretenie relates to a hydraulic construction and can be used for the purification of river channels, canals The aim of the invention is to develop a method and to create an apparatus using the flow velocity of the river in the most optimal manner. The technical result of the proposal The method is simplified, and optimization of one of the existing methods for cleaning river beds and canals, increasing its functionality (Figure 3).

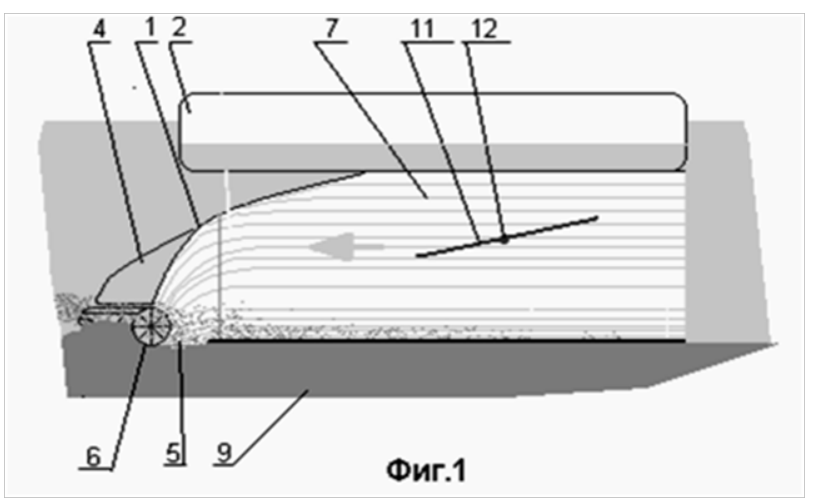

Figure 3 Cleaning river beds and canals, increasing its functionality.
US Patent, № 870621. Flood situation in the North-Kazakhstan region remains alarming Photos of Tamara Tamara Vaal Vaal, Astana. ${ }^{2}$ Kalmukhanbet Interior Minister Kasimov said the alarming flood Situation on the territory of the North-Kazakhstan region. Due to the great overcrowding Sergeevskoye reservoir in the suburbs of Petropavlovsk flooded 170 houses. "As the flood situation would like to say that we have a worrying situation in the Northern Kazakhstan. All the water that was Karaganda and Akmolinsk region came to Sergeevskyreservoir, and $138 \%$ more filled from the norm. Is overflowing and it fills all the villages and suburbs of Petropavlovsk there are now about 170 houses are flooded, "- said Kasimov on Friday during the governmental hour in senate. istochnik ${ }^{3}$ (Figure 4).

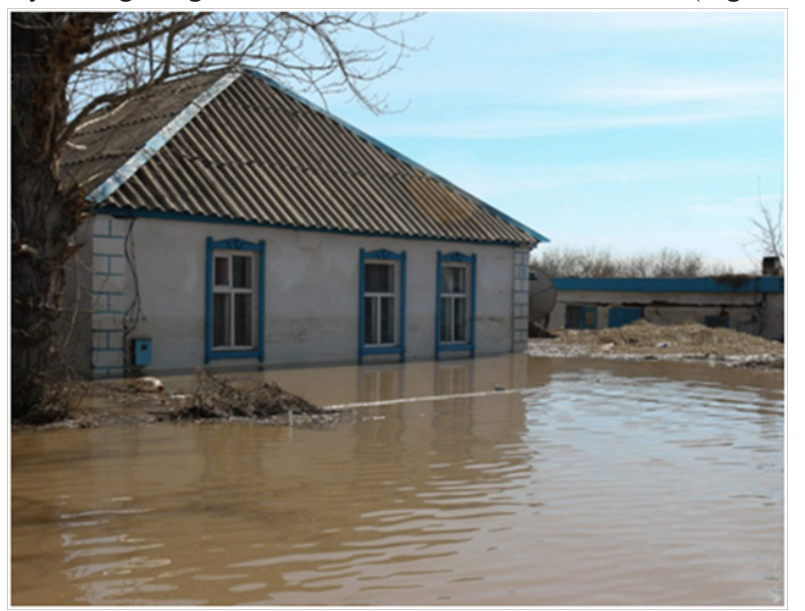

Figure 4 Flood Situation on the territory of the North-Kazakhstan region.

\section{Acknowledgments}

None.

\section{Conflicts of interest}

None.

\section{References}

1. https://www.aquamec.rc/?yclid=2500461208821832434

2. https://vlast.kz/tags/pavodki/?page=3

3. https://ru.sputniknews.kz/incidents/ 